\title{
Conversations in Male Genderlect in Young Adult Fiction: Their Effect on Reading Motivation
}

\author{
Howard B. Parkhurst \\ Central Michigan University, Mt. Pleasant, Michigan 48859, USA
}

\begin{abstract}
A study was conducted to test the hypothesis that eighth grade young adults would indicate greater motivation to read books with accurate representation of conversations in male genderlect, with genderlect being defined as "a set of linguistic features that characterizes language production of a socially defined gender category (typically woman/girl and man/boy)" (Johnson, 2009). Fifty-six eighth grade volunteers--29 female and 27 male--were presented with five excerpts from young adult novels that contained conversations in male genderlect. These excerpts were paired with the same conversation re-written in Standard English. Subjects were asked to indicate which seemed more like a book they would like to read--the male genderlect version or the Standard English version. The hypothesis was not supported.
\end{abstract}

Index Terms - literacy, young adult literacy, adolescent literacy, young adult males and literacy, young adult literature, reading motivation, genderlect

\section{INTRODUCTION}

An ongoing source of concern regarding the preparation of young adults with skills needed for success in college and the workplace has been the disparity in male and female literacy achievement (Brozo, 2010; Cypress, A. \& LeeAnderson, K. ,2011; Mitchell, Murphy, \& Peters, 2008; Sadowski, 2010; Whitmire, 2006). As examples, both 13-yearold and 17-year old females have out-scored males on the long term National Assessment of Educational Progress with every test administration since its inception in 1971 (National Center for Educational Statistics, 2012); females outscore males on the ACT (Conrad-Curry, 2010/2011); and in every state, fewer males score proficient or higher in reading on every state accountability test (Brozo, et al., 2014; Sadowski, 2010).

A variety of explanations exists for this lackluster male performance, but most ascribe the source of the problem to lower male reading motivation and engagement, with motivation defined as the willingness to engage in an activity, and a willingness to persist in that activity even when it becomes difficult (Urdan \& Schoenfelder, 2006), and engagement comprising three dimensions: enjoyment of reading, time spent reading for enjoyment, and diversity of texts read (Brozo, et al., 2014).

Some point to biological differences in male and female anatomy as reasons for the lesser male motivation to read. For example, brain research by Harasty, Double, Halliday, Kril, and McRitchie (1997) has found that Broca's area and Wernicke's area, the parts of the brain that govern language, are considerably larger in females than in males. Senn (2012) states that at school entry age in the United States, the language areas of the average boy's brain are developmentally 1.5 years behind the average girl's. Leonard Sax notes that boys' and girls' eyes are structured differently at birth, with boys' eyes built to answer the questions, "Where is it, and where is it going?", while girls' eyes are constructed to answer the question, "What is it?" Thus, boys' eyes are less well-prepared to focus on static figures on a page (Sax, 2005). Consequently, for these and other reasons, the logic goes, since boys are less well-prepared developmentally for reading instruction, they find it harder and are less successful than girls. People tend to like to engage in those activities at which they experience success and avoid those at which they do not, as indicated by Bandura's self-efficacy theory (Bandura, 1977). Consequently, males form a negative view of reading as an activity early on in school and become more prone to avoid it.

Others consider socialization into gender roles as a primary factor, suggesting that because children's mothers are the most likely parents to read to them, and elementary teachers and librarians are overwhelmingly female, boys rapidly develop the idea that reading is a feminine activity. Mitchell, Murphy, and Peters (2008) stated that part of some boys' low reading motivation is that they see reading to be in conflict with their sense of masculinity. According to the Canadian Council on Learning (2009, Feb. 18) some boys form the perception that reading is female in nature by the time they start school, with 24 percent of second grade boys stating that reading is a feminine activity and therefore not something that boys should enjoy or engage in voluntarily.

A third view, related to the first two, but different in focus, holds that the types of instructional materials in reading and English classes do not match boys' interests. Research indicates that boys in general are interested in non-fiction and stories with male main characters, strong action and adventure-filled plots, humor, texts that stimulate visual thinking, edgy or slightly subversive texts that offer a divergent angle or are shocking in some way, texts in which they 
can see themselves and their concerns, and short chapters that provide feelings of competence and accomplishment (Brozo, 2010; Newkirk, 2002; Parkhurst, 2008; Scieszka, 2002; Serafini, 2013; Smith \& Wilhelm, 2002; Tatum, 2005; Zbaracki, 2008).

Thus, the male enjoyment of non-fiction means that the importance that Common Core standards place on nonfiction is overdue. However, it would be a mistake to deduce from this that boys do not like fiction narrative or that fiction narrative holds little value for them. If boys did not like fiction narrative, they would not be avid fans of fiction narrative in movie format like the Transformer series or so fascinated by stories from Greek and Roman mythology like Perseus's rescue of Andromeda from the sea monster. In fact, MRI studies show that the same regions of the brain are activated while reading a fiction story as are activated during a real event. Reading a story lets readers enter vicariously into the thoughts, feelings, and problems of others. It is a form of practice for real life, and evidence indicates that readers of fiction narrative are better able to understand other people, a quality not true of those who read primarily nonfiction (Diakiaw, 2014). As Smith and Wilhelm put it, fiction narrative provides "imaginative rehearsals for living" (Smith \& Wilhelm, 2002, p. 164). However, action-oriented stories of the sort likely to motivate boys to read were largely removed from school curricula decades ago in well-intentioned initiatives to remove violence from children's reading (Sadowski, 2010, Nov.) to be replaced by texts used in reading and literature instruction that typically focus on characters' personalities and emotional issues, topics which tend not to match the reading preferences of adolescent males for action and humor (Senn, 2012; Serafini, 2013).

In Reading Don't Fix No Chevys, Smith and Wilhelm's 2002 study of the literacy practices and preferences of 49 adolescent boys, they identified an overarching quality they called the "reality principle," the ability for male readers to see themselves and their concerns in the text (Smith \& Wilhelm, 2002, p. 123.) Even the boys who were followers of fantasy and science fiction insisted on those books' "reality," because they helped them with real life situations.

One of the characteristics that would seem to be a likely component of a narrative's "reality" would be conversational language used in the way an adolescent male, unaware he is being observed, would use it in a school hallway or locker room. This particular type of language is known as "male genderlect."

A "dialect" is "a regional variety of language distinguished by features of vocabulary, grammar, and pronunciation from other regional varieties and constituting together with them a single language<the Doric dialect of ancient Greek>" (Merriam-Webster Dictionary, 2015). A "sociolect" is "a variety of a language that is used by a particular social group" ( Merriam- Webster Dictionary, 2015). An example would be lower class residents of New York City. An "idiolect" is "the language or speech pattern of one individual at a particular period of life" (Merriam-Webster Dictionary, 2015). Male and female "genderlect" refer to language used in ways peculiar to one gender or the other. The term was first used by Cheris Kramer (later Kramerae) in 1974, who noted that the sex of a speaker can be identified even when there is no difference in articulatory mechanism (Kramer, 1974). It was later popularized and brought into more widespread usage by sociolinguist Deborah Tannen in her best-seller, You Just Don't Understand: Women and Men in Conversation (1990). A "genderlect," then, is "a set of linguistic features that characterizes language production of a socially defined gender category (typically woman/girl and man/boy)" (Johnson, 2009).

Though the differences in male and female speech patterns had been explored as early as the 1920's, most notably by Otto Jespersen (1922), the subject was only occasionally explored until the 1970's when Robin Lakoff (1973) sparked a great deal of interest in the topic on the part of feminist researchers. Looking at differences in the ways men and women talk from a feminist perspective, these researchers tended to assume that those differences resulted from men's desire to dominate women or "keep them in their place" (e.g., Edelsky, 1978; Kramerae, 1981), citing as evidence, for example, research that shows that in conversation, men interrupt women more than vice versa (Zimmerman \& West, 1978).

More research on male-female conversation patterns has tended to refute this view, demonstrating that men also interrupt other men, and women interrupt other women, but that their reasons for interrupting differ: Men interrupt male speakers as a means of establishing status, while women tend to interrupt other women to show support or agreement (Tannen, 1990; Griffin, Ledbetter, \& Sparks, 2015). Males do, in fact, seem far more concerned with asserting dominance when interacting with other males than when interacting with females (Leaper \& Ayres, 2007).

Documented differences such as this establish that peculiarly male and female voices, or genderlects, exist. They develop, according to Tannen (1990), because children tend to play in gender-segregated groups, interacting primarily with others of the same sex, consequently growing up in what amount to two different cultures. Each genderlect has its own sociolinguistic rules and is important to a speaker's identity construction, including the construction of gender (Kramerae, 1981; Warfel, 1984; Kehler, Davison, \& Frank, 2005). The hierarchical social order views taken by males tend to make male genderlect conversations into negotiations for status, with speakers trying to protect their social rank from others' attempts to diminish it. Conversations in female genderlect, on the other hand, reflect attempts to negotiate connections and degrees of intimacy.

Blair (2000) observed how middle school boys engage in constant competition for status, trying to outdo each other's ability to elicit laughter from classmates. Other attempts to raise speakers' status involve casting aspersions on others' masculinity. For example, in Robert Lipsyte's Raiders Night (2006), one of the football team's fullbacks continually refers scornfully to other players as "girls." Women and girls do not generally try to diminish the femininity of other females by referring to them in masculine terms. 
Other differences between male and female genderlect include a greater male propensity for slang and non-standard English; a greater tendency to drop the $g$ in -ing verbs; lesser use of intensifiers like more, most, and better; the use of fewer qualifiers such as awfully, somewhat, or rather; lesser employment of hedges such as kind of, sort of, I guess, et cetera; a greater propensity for swear words and when swearing to use more explosive expletives (Fuck!'); use of fewer tag questions such as "College tuition is getting to be awfully expensive, isn't it?" or "Community college classes should be free, don't you think?"; male avoidance of adjectives and color words considered feminine in nature, such as lovely, charming, marvelous, lavender, ecru, mauve, et cetera. (Kramerae, 1981; Tannen, 1990; Golderg, 1994; Xia, 2013; Griffin, Ledbetter, \& Sparks, 2015).

Additionally, male questions, comments, and compliments tend to be one or two words in length or short phrases. The female question, “Are we going now?" becomes in male genderlect, "We goin'?" The female compliment "That coat looks nice on you" becomes "Hey! Nice coat!" (O’Donohue \& Crouch, 1996; Wilkinson, 1999). The following example of this abbreviated form of male conversation is taken from Robert Lipsyte's Raiders Night (2006):

Brody asked, "You going to Lexie's?

"You?"

Brody shrugged. "Might as well. Last party before hell."

"Pick me up after the game?"

"I'm driving?"

"Your turn," said Matt.

"What about Pete?"

"Who knows? Might have to paint Lisa's toenails tonight." (p.10)

(Pete is a friend of Matt and Brody's whom they think spoils his girlfriend and thus would probably be willing to paint her toenails.).

This sort of extended dialogue in male voice or genderlect is rare in young adult literature aimed at a male audience. Parkhurst (2012) examined over 200 young adult novels aimed at adolescent boys and found only 11 that contained more than incidental use of conversation in recognizably realistic male genderlect. However, if, as Kehler, Davison, and Frank (2005) said, language helps constitute gender, then accurate representation of male genderlect could become part of male adolescents' ability to see themselves and identify with characters in young adult fiction. It would then become part of the fulfillment of Smith and Wilhelm's "reality principle."

\section{METHOD}

Children's book author Jon Scieszka (2003) noted the importance of accurate representation of nine-year-olds' dialogue in books aimed at that age level. Logically, adolescent girls would also prefer fiction that depicted male characters speaking in the same manner as men and boys with whom they are familiar. Yet no one seems to have investigated the importance to young adults' reading motivation of the accurate representation of male or female dialogue in books aimed at teenagers. The study described below was conducted to test the following hypothesis:

Eighth grade young adults will indicate greater motivation to read books with accurate representation of conversations in male genderlect.

The subjects were 56 eighth grade volunteers from a rural Midwestern United States school district, 29 female and 27 male, who were released from class to participate in the study. The district's population is a mix of middle class and lower socioeconomic status households. All of the subjects were Caucasian of apparent European ancestry, though they were not queried about their ethnic or racial background. The instrument consisted of a packet with five passages from young adult novels that accurately display conversations in male genderlect. These conversational passages were paired with the same conversations re-written in Standard English (neutral genderlect). In three of the paired passages, the male genderlect version was on the left, while in two, the male genderlect version was on the right. This was done to reduce the likelihood that subjects would simply choose all of the left hand passages or all of the right. To the left of each passage was a box. Subjects were asked to indicate, by placing an $\mathrm{X}$ in the box next to that passage, which one out of each pair sounded more like a book they would like to read. To decrease the likelihood that subjects would recognize a book as one they had already read or an author with whose works they were familiar, the sources of the passages were not identified in the instrument. They were, however, taken from Sleeping Freshmen Never Lie (Lubar, 2005), a book about a young man surviving his freshman year of high school; Yellow Flag, (Lipsyte, 2007), a novel about auto racing; Vision Quest (Davis, 2002), a coming of age novel about wrestling; Raiders Night ( Lipsyte, 2006), a story concerning high school hazing and jealousy; and If You're Reading This (Reedy, 2014), a book about a teenage boy grieving his father who died in Afghanistan. (The instrument can be found in the appendix following this article.)

After subjects had assembled in the school cafeteria, the researcher read the directions aloud to them. Though the passages contained very few words that would be likely to cause trouble for an eighth grader, subjects were told that if they found an unfamiliar word, they should raise a hand, and the researcher would provide it. They were cautioned against comparing or discussing answers. As subjects completed the exercise, the researcher picked up their papers which subjects had been directed to place in researcher-supplied plain blank envelopes.

\section{RESULTS}


Subsequent analysis of the data indicated the hypothesis was not supported. In no case did a majority of the subjects indicate a preference for the passage in male genderlect form. (See Table 1.) The closest subjects came to an even split in their preferences was on the second and third excerpts, from Yellow Flag (Lipsyte, 2007) and Terry Davis's Vision Quest (2002), for which 21, or 38 per cent, indicated a preference for the male genderlect form. Approximately onethird, 19 subjects, or 34 percent, indicated a preference for the fifth excerpt, from Reedy's If You're Reading This (2014). In each of these three cases, while the overwhelming majority of subjects chose the Standard English version, a substantial minority did prefer the male genderlect rendering.

TABLE 1

Percentage of SubJects Preferring Male Genderlect Forms of Young Adult Novel Conversations (N=56)

\begin{tabular}{|l|l|l|l|l|}
\hline \multicolumn{2}{|l|}{ Standard English } & $\%$ & Male Genderlect \\
\hline Novel Title & $\begin{array}{l}\text { Number of Subjects } \\
\text { Making This Choice }\end{array}$ & $\begin{array}{l}\text { Number of Subjects } \\
\text { Making This Choice }\end{array}$ & \% \\
\hline $\begin{array}{l}\text { Sleeping Freshmen Never Lie } \\
\text { (Lubar, 2005), Excerpt 1 }\end{array}$ & 44 & $79 \%$ & 12 & $21 \%$ \\
\hline $\begin{array}{l}\text { Yellow Flag (Lipsyte, 2007), } \\
\text { Excerpt 2 }\end{array}$ & 35 & $63 \%$ & 21 & $38 \%$ \\
\hline $\begin{array}{l}\text { Vision Quest (Davis, 2002), } \\
\text { Excerpt 3 }\end{array}$ & 35 & $63 \%$ & 21 & $38 \%$ \\
\hline $\begin{array}{l}\text { Raiders Night (Lipsyte, 2006) } \\
\text { Excerpt 4 }\end{array}$ & 45 & $80 \%$ & 11 & $20 \%$ \\
\hline $\begin{array}{l}\text { If You're Reading This } \\
\text { (Reedy, 2014), Excerpt 5 }\end{array}$ & 37 & $66 \%$ & 19 & $34 \%$ \\
\hline
\end{tabular}

The 29 female subjects overwhelmingly indicated a preference for the Standard English version of the conversations. (See Table 2.) The greatest number who chose the male genderlect version were the eight girls, or 28 percent, who preferred that version of the conversation in the second excerpt, from Robert Lipsyte's Yellow Flag (2007). Only four percent indicated a preference for the male genderlect form of the conversation in the first excerpt, from Sleeping Freshmen Never Lie (Lubar, 2005), which interestingly enough was about the main character querying his father about how he and the boy's mother became acquainted.

TABLE 2

Percentage of Female SubJects Preferring Male Genderlect Forms OF Young Adult Novel CONVERSATIONS (N=29)

\begin{tabular}{|c|c|c|c|c|}
\hline & \multicolumn{2}{|l|}{ Standard English } & \multicolumn{2}{|l|}{ Male Genderlect } \\
\hline Novel Title & Number of Subjects Making This Choice & $\%$ & Number of Subjects Making This Choice & $\%$ \\
\hline $\begin{array}{l}\text { Sleeping Freshmen Never } \\
\text { Lie (Lubar, 2005), Excerpt } 1\end{array}$ & 25 & $86 \%$ & 4 & $14 \%$ \\
\hline $\begin{array}{l}\text { Yellow Flag (Lipsyte, } \\
\text { 2007), Excerpt } 2\end{array}$ & 21 & $72 \%$ & 8 & $24 \%$ \\
\hline $\begin{array}{l}\text { Vision Quest (Davis, 2002), } \\
\text { Excerpt } 3\end{array}$ & 22 & $76 \%$ & 7 & $24 \%$ \\
\hline $\begin{array}{l}\text { Raiders Night (Lipsyte, } \\
\text { 2006) Excerpt } 4\end{array}$ & 24 & $83 \%$ & 5 & $17 \%$ \\
\hline $\begin{array}{l}\text { If You're Reading This } \\
\text { (Reedy, 2014), Excerpt } 5\end{array}$ & 22 & $76 \%$ & 7 & $24 \%$ \\
\hline
\end{tabular}

The 27 male subjects took a much more favorable view of the male genderlect forms of the conversations with 15 , or 56 percent, choosing the male genderlect version of Terry Davis's Vision Quest (2002) and nearly half (13 or 48 percent) choosing the male genderlct form of the dialogue from Robert Lipsyte's Yellow Flag (2007). (See Table 3). This was the one male genderlect version that a majority of either boys or girls chose. The fewest boys chose the Raiders Night (Lipsyte, 2006) male genderlect rendering-- six, or 22 percent.

TABLE 3

Percentage of Male SubJects Preferring Male Genderlect Forms OF Young Adult Novel Conversations (N=27)

\begin{tabular}{|l|l|l|l|l|}
\hline & \multicolumn{2}{l|}{ MERCENTAGE OF MALE SUBJCTS PREFERRING MALE GENDERLECT FORMS OF YUderlect } \\
\hline Novel Title & Standard English & $70 \%$ & 8 & \multicolumn{2}{l|}{} \\
\hline $\begin{array}{l}\text { Sleeping Freshmen Never } \\
\text { Lie (Lubar, 2005), Excerpt 1 }\end{array}$ & 19 & $52 \%$ & 13 & $30 \%$ \\
\hline $\begin{array}{l}\text { Yellow Flag (Lipsyte, } \\
\text { 2007), Excerpt 2 }\end{array}$ & 14 & $44 \%$ & 15 & $48 \%$ \\
\hline $\begin{array}{l}\text { Vision Quest (Davis, 2002), } \\
\text { Excerpt 3 }\end{array}$ & 12 & $78 \%$ & 6 & $56 \%$ \\
\hline $\begin{array}{l}\text { Raiders Night (Lipsyte, } \\
\text { 2006) Excerpt 4 }\end{array}$ & 21 & $56 \%$ & 12 & $22 \%$ \\
\hline $\begin{array}{l}\text { If You're Reading This } \\
\text { (Reedy, 2014), Excerpt 5 }\end{array}$ & 15 & $44 \%$ & \\
\hline
\end{tabular}


Given Smith and Wilhelm's (2002) reality principle, the importance of language to the construction of gender ((Kramerae, 1981; Warfel, 1984; Kehler, Davison, \& Frank, 2005), and Jon Scieszka's 2002 comments about the importance of realistic dialogue, the intuitive results would have had subjects overwhelmingly choosing the male genderlect form of each set of dialogues, the boys because that form mirrored the way they talk to each other, and the girls because that is how the males with whom they are familiar speak to each other. So why was this not the case?

First of all, it would clearly be mistaken to suggest that no subjects preferred the male genderlect versions, as over a third of all subjects opted for that style of the second, third, and fifth excerpts, from Robert Lipsyte's Yellow Flag (2007), Terry Davis's Vision Quest (2002), and Trent Reedy's If You're Reading This (2014). This is a minority of subjects, but a substantial minority. And, although the study was not set up or intended to disaggregate data by gender, it is nevertheless true that over half (56 percent) of the male subjects chose the male genderlect version of the third excerpt, from Vision Quest, and nearly half (48 percent and 44 percent, respectively) chose the male genderlect form of the excerpts from Yellow Flag and If You're Reading This.

Why these particular sets of conversation is difficult to surmise. There is nothing about the excerpt from Vision Quest to indicate that the book centers around wrestling or even sports, except that Otto saw Louden Swain's "norms" in the shower. The excerpt from Yellow Flag includes the word race, and the subject is use of the "sling," a stock car racing maneuver. Would a set of eighth grade boys be familiar enough with NASCAR racing to recognize the topic? It is possible, but seems questionable. And there is nothing in the excerpt from If You're Reading This to indicate that the main character's father is dead, even though the boy is receiving letters from him, though it does mention four-wheeling and a pasture, which might be relevant to the habitus of some rural youth. The excerpt from Raiders Night also clearly relates to a sport of some kind (though it is not clear that the sport is football), yet that was not popular with the group as a whole or with the boys. The first excerpt, from Sleeping Freshmen Never Lie, relates to burgeoning early malefemale relationships. Perhaps in that case, it did not meet subjects' tastes, but otherwise, none of the other passages should be more likely than any other to pique the interest of eighth graders. Vision Quest is easily the most difficult of the books as far as reading level is concerned--sporting the words anomie, sociology, and norms-yet was one of those books more commonly chosen.

Despite the male genderlect forms of the sets of conversations being what would seem to be their intuitive choice, subjects did, then, in general show a preference for the Standard English versions of the conversations. Although subjects were released from a variety of classes to participate in the study, they were introduced to it in their English classes, and the teacher whose cooperation made the study possible was their English teacher. While school by and large tends to encourage the use of Standard English, the class with which students most associate the use of "correct" grammar and writing in complete sentences is English. It may be that the study's connection with English class led some to feel they "should" choose the Standard English rendition, despite the directions to choose the one they felt sounded most like a book they would like to read. It would be worthwhile to replicate the study in another setting and execute it through the assistance of a teacher in some other discipline, such as mathematics or physical education, or a counselor - or in a setting other than a school.

The girls in particular opted for the Standard English version of each set of conversations. (See Table 2.) Research indicates that female genderlect is marked by a greater emphasis on the use of "correct" grammar (Kramerae, 1981; Tannen, 1990; Golderg, 1994; Xia, 2013; Griffin, Ledbetter, \& Sparks, 2015). Perhaps the girls chose the Standard English or neutral genderlect versions because they were closer to their own speaking style.

Greater understanding of subjects' choices could perhaps be obtained by asking them to provide a sentence or two explaining the reasoning behind each choice, although the instructions to choose the passage from each of the pairs that most sounds like a book they would like to read are pretty straightforward and direct.

\section{LIMITATIONS AND SUGGESTIONS FOR FURTHER RESEARCH}

As indicated earlier, the subjects were 56 eighth grade volunteers out of a total eighth grade population of 129 from a relatively small middle school in the rural Midwest. Since the 56 subjects represent fewer than half of the school's eighth grade, it is possible that their responses are not indicative of the attitudes of other eighth graders at the school. The entire middle school has about 450 students, making it a relatively small school. More research needs to be done to determine if the results of this small study are generalizable to other settings. Additionally, the attitudes of eighth graders may differ from those of older adolescents; very similar studies might yield very different responses from 15- or 17-year-olds.

Further, the study's purpose was to look at the responses of eighth graders in general. Had the purpose been different and the hypothesis worded differently as a consequence, results would have indicated that boys were more likely to choose the male genderlect versions than girls were, though in only one case (Terry Davis's 2002 Vision Quest excerpt) did a slim majority of boys do so. This also needs to be examined in further research.

\section{SUMMARY}

A study was conducted to test the hypothesis that eighth grade young adults would indicate greater motivation to read books with accurate representation of conversations in male genderlect. The hypothesis was not supported. In each of 
five instances of paired conversations from young adult novels, one in male genderlect, the other the Standard English version, the overwhelming majority of subjects chose the Standard English version. Boys were, however, more likely than girls to choose the male genderlect form.

\section{APPENDIX}

Please indicate whether you are male or female by circling the appropriate choice:

\section{MALE FEMALE}

Below and on the next two pages, you'll find four pairs of conversations taken from novels for young adults. The one on the left and the one on the right are the same conversation, but written a little differently.

Please read through them and put an $\mathrm{X}$ in the box next to the one you think sounds more like a book you would enjoy reading.

$\square$ "So how is school going? Dad asked.

"School's going good."

"I'm glad to hear it."

"Dad?"

"Yeah?"

"Did Mom notice you right away?"

He shook his head.

"So what did you do?"

"I showed up."

"Where did you show up?"

"I showed up wherever she was."

"So you showed up wherever she was?"

"Or wherever she might be."

"That must have taken a lot of time," I said.

Dad shrugged. "She was worth it."

Dad shrugged... "You kind of leave yourself

real vulnerable with the sling."

"Wouldn't have won otherwise."

"True. When you boys cook that up?"

Never lie to Dad. "Just before the race."

He nodded. "Kris been practicing it?"

"Not that I know."

"Kale's pretty wound up. If Kris misses any races, he's going to chew your ear."

"He already did."

“What's wrong, Nort?” I ask. You look bad.” ... "I have no norms," Norty whines. "And also I'm hungry."

"What don't you have, Nort?" asks Otto.

"Norms. I have no norms. None of us do.

Mr. Bronson says we live in a time of anomie." Mr. Bronson teaches sociology.

"Louden has some norms," replies Otto.

I saw them yesterday in the shower."

(Swain is Louden's last name.)

Brody asked, "Are you going to Lexie's?”

"You?"

Brody shrugged. "Might as well. Last party

before hell."

"Pick me up after the game?"

"I'm driving?"

"Your turn," said Matt.

"What about Pete?"

"Who knows? Might have to paint Lisa's toe-
"So how is school going?" Dad asked

"Good."

"Glad to hear it."

"Dad?"

"Yeah?"

"Did Mom notice you right away?"

He shook his head.

"So what did you do?"

"Showed up."

"Where?"

"Wherever."

"So you showed up wherever she was?"

"Or wherever she might be."

"That must have taken a lot of time," I said.

Dad shrugged. "Worth it."

Dad shrugged..."You kind of leave yourself really vulnerable with the sling."

"We wouldn't have won otherwise."

"That's true. When did you boys cook that up?

Never lie to Dad. "We decided just before the race."

He nodded. "Has Kris been practicing it?"

"Not that I know of."

"Kale is pretty wound up. If Kris misses any races, he's going to really yell at you."

"He already did."

"What's wrong, Nort?" I ask. You look bad." "I got no norms, " Norty whines. "And also I'm hungry."

"What don't you have, Nort?" asks Otto.

"Norms. I got no norms. None of us do. Mr. Bronson says we live in a time of anomie." Bronson teaches sociology. "Swain's got some norms," replies Otto. "I saw 'em yesterday in the shower."

Brody asked, "Are you going to Lexie's?"

"Are you going?"

Brody shrugged. "I might as well. It's the

last party before hell."

"Will you pick me up after the game?"

"I'm going to drive?"

"It's your turn," said Matt.

"What about Pete?"

"Who knows? He might have to paint 
nails tonight.

"You're getting letters from your dad?"

Was he playing dumb to throw me off the trail? But why would anyone do that? "Yes, I am. Do you know who is sending them?" "Wow, kid, I wish I did. Sorry. Me and your dad was great friends. He tell you about the time we was four-wheeling in my parents' pasture, and I crashed the thing and broke my leg?" "No, he didn't," I said. Todd laughed. "It was a bad break. Bone sticking out through the skin and blood everywhere. No cell phones in them days, you see. Couldn't call for help. Your old man bandaged me up with his own shirt and then carried me all the way back to my father's house ... Great man, your father. "

own shirt and then carried me all the
Lisa's toenails tonight."

"You're getting letters from your dad?" Was he playing dumb to throw me off the trail? But why would anyone do that? "Yes, I am. Do you know who is sending them?"

"Wow, kid, I wish I did. Sorry. Your dad and I were great friends. Did he tell you about the time we were four-wheeling in my parents' pasture, and I crashed the thing and broke my leg?"

"No, he didn't," I said

Todd laughed. "It was a bad break. The bone was sticking out through the skin, and there was blood everywhere. There weren't any cell phones in those days, you see. We couldn't call for help. Your father bandaged me up with his way back to my father's house... Your father was a great man.”

\section{REFERENCES}

[1] Bandura, A. (1977). Self-Efficacy: Toward a unifying theory of behavioral change. Psychological Review, 84, 191-215.

[2] Blair, H. (2000). Genderlects: Girl talk and boy talk in a middle school classroom. Language Arts, 77, 315-323.

[3] Bozack, A. (2011). Reading between the lines. The High School Journal, 94 (2), 58-76.

[4] Brozo, W. (2010). To be a boy, to be a reader. Newark, DE: International Reading Association.

[5] Brozo, W. G., Sulkinen, S., Shiel, G., Garbe, C., Pandian, A., \& Valtin, R. (2014). Reading, gender and engagement: Lessons from five PISA countries. Journal of Adolescent and Adult Literacy, 57, 584-593.

[6] Canadian Council on Learning. (2009, Feb. 12). Lessons in learning: Why boys don't like to read: Gender differences in reading achievement. Retrieved Nov. 23, 2015 from http://bigleaguebookclub.ca/ blbc/wpcontent/uploads/2015/02/lessons.pdf.

[7] Conrad_Curry, D. (2010/2011). A four-year study of ACT reading results: Achievement trends among eleventh-grade boys and girls in a Midwestern state. Journal of Education, 191(3), 27-37.

[8] Cypress, A. \& Lee-Anderson, K. (2011). The impact of boys and literacy: Connecting boys with books, engaging the adolescent reader. The International Journal of Interdisciplinary Social Sciences, 5 (10), 59-71.

[9] Davis, T. (2002). Vision quest. Spokane, WA: Eastern Washington University Press.

[10] Diakiwa, J. (2014). The power of engaged reading. Retrieved Nov. 15, 2015, from http://www.cea.ca/educationcanada.

[11] Edelsky, C. (1978, Nov.). Genderlects: A brief review of the literature. Paper presented at the $68^{\text {th }}$ annual meeting of the National Council of the Teachers of English. Kansas City, MO.

[12] Goldberg, M. (1994). Sex stereotypes as a function of genderlect. Totem: The University of Western Ontario Journal of Anthropology, 1 (1), 75-79.

[13] Griffin, E., Ledbetter, A., \& Sparks, G. (2015). Genderlect styles of Deborah Tannen. In A first look at communication theory (pp. 432-443). New York: McGraw-Hill.

[14] Harasty J., Double K.L., Halliday, G.M., Kril, J.J., and McRitchie, D.A. (1997). Language-associated cortical regions are proportionally larger in the female brain. Archives in Neurology. 54 (2) 171-6.

[15] Jespersen, O. (1922). Language, its nature, development and origin. New York: Henry Holt and Company.

[16] Johnson, F. L. (2009). Genderlect theory. In S. W. Littlejohn \& K. A. Foss (Eds.). Encyclopedia of Communication Theory (pp.431-433). Thousand Oaks, CA: Sage.

[17] Kehler, M. D., Davison, K. G., \& Frank, B. (2005). Contradictions and tensions in the practice of masculinities in school: Interrogating embodiment and "good buddy" talk. JC T, 21(4), 59-72.

[18] Kramer, C. (1974). Women's speech: Separate but unequal? Quarterly Journal of Speech, 60 (1), 14-24.

[19] Kramerae, C. (1981). Women and men speaking. Rowley, MA: Newbury House.

[20] Lakoff, R. (1973). Language and woman's place. Language in Society, 2 (1), 45-80.

[21] Leaper, C. \& Ayres, M. M. (2007). A meta-analytic review of gender variations in adults' language use: Talkativeness, affiliative speech, and assertive speech. Personality and Social Psychology Review, 11, 328-363.

[22] Lipsyte, R. (2006). Raiders night. New York: HarperCollins.

[23] Lipsyte, R. (2007). Yellow flag. New York: HarperCollins

[24] Lubar, D. (2005). Sleeping freshmen never lie. New York: Penguin.

[25] Malloy, M. A., Marinak, B. A., Gambrell, L. B., \& Mazzoni, S. A. (2013). Assessing motivation to read: The motivation to read profile-revised. The Reading Teacher, 67, 273-282.

[26] Merriam-Webster.com. (2015). Dialect. In Merriam-Webster Dictionary. Retrieved Feb. 24, 2016 from http://www.merriamwebster.com/dictionary/dialect. 
[27] Merriam-Webster.com. (2015). Idiolect. In Merriam-Webster Dictionary. Retrieved Feb. 24, 2016 from http://www.merriamwebster.com/dictionary/idiolect.

[28] Merriam-Webster.com. (2015). Sociolect. In Merriam-Webster Dictionary. Retrieved Feb. 24, 2016 from http://www. merriamwebster.com/dictionary/sociolect.

[29] Mitchell, R., Murphy, R. M., \& Peters, J.M. (2008). The boys in literacy initiative: Molding adolescent boys into avid readers. Retrieved Nov. 28, 2015 from https://www.naesp.org/resources/2/Principal/2008/M-Ap70.pdf.

[30] National Center for Educational Statistics. (2012). NAEP-2012 Long-term trend: Age 17 reading results. Retrieved Feb. 24, 2016 from http://www.nationsreportcard.gov/ltt_2012/age17r.aspx.

[31] National Center for Educational Statistics. (2012). NAEP-2012 Long-term trend: Age 17 reading results. Retrieved Feb. 24, 2016 from http://www.nationsreportcard.gov/ltt_2012/age17r.aspx.

[32] Newkirk, T. (2002). Misreading masculinity Boys, literacy, and popular culture. Portsmouth, NH: Heinemann.

[33] O'Donohue, W. \& Crouch J. L. (1996). Marital therapy and gender-linked factors in communication. Journal of Marital and Family Therapy, 22, 87-101.

[34] Parkhurst, H. B. (2008). Engaging male adolescents in reading: Humor in young adult fiction. Charter Schools Resource Journal, 1-10.

[35] Reedy, T. (2014). If you're reading this. New York: Arthur A. Levine/Scholastic.

[36] Sadowski, M. (2010, Nov.). Putting the 'boy crisis' in context. Education Digest, 76 (3), 10-13.

[37] Sax, L. (2005). Why gender matters. New York: Broadway Books/Random House.

[38] Scieszka, J. (2002, March). Getting guys to read. NEA Today, 20, 23.

[39] Scieszka, J. (2003). Guys and reading. Teacher Librarian, 30 (3), 17-18.

[40] Senn, N. (2012). Effective approaches to motivate and engage reluctant boys in literacy. The Reading Teacher, 66, 211-220.

[41] Serafini, F. (2013). Supporting boys as readers. The Reading Teacher, 67 (2), 40-42.

[42] Smith, M. W. \& J. D. Wilhelm. (2002). Reading don't fix no Chevys, Portsmouth, NH: Heinemann.

[43] Tannen, D. (1990). You just don't understand: Women and Men in conversation. New York: HarperCollins.

[44] Tatum, A. (2005). Teaching reading to black adolescent males. Portland, ME: Stenhouse.

[45] Urdan, T., \& Schoenfelder, E. (2006). Classroom effects on student motivation: Goal structures, social relationships, and competence beliefs. Journal of School Psychology, 44, 331-349.

[46] Warfel, K. A. (1984). Gender schemas and perceptions of speech style. Communication Monographs, 51, $253-257$.

[47] Whitmire, R. (2006, Jan. 23). Boy trouble. The New Republic, 234, 15-18.

[48] Wilhelm, J. D., \& Smith, M. W. (2014). Reading don't fix no Chevy's (Yet!): Motivating boys in the age of the Common Core. Journal of Adolescent and Adult Literacy, 58, 273-276.

[49] Wilkinson, K. M. (1999). Gender diffences in the use of linguistic devices by youths with mental retardation. American Journal of Mental Retardation, 104 (3), 227-235.

[50] Xia, X. (2013). Gender differences in using language. Theory and Practice in Language Studies, 3, 1485-1489.

[51] Zbaracki, M. D. (2008). Best books for boys: A resource for educators. Westport, CT: Libraries Unlimited.

[52] Zimmerman, D. H. \& West, C. (1978). Male-female differences in patterns of interruption and responses to interruption in twoparty conversations. Paper presented at the Ninth World Congress of Sociology, Uppsala, Sweden.

Howard B. Parkhurst is currently an associate professor of curriculum and instruction at Central Michigan University in Mt. Pleasant, Michigan USA. He holds a Ph. D. in K-12 Curriculum from Wayne State University in Detroit, Michigan, a Master's degree in reading instruction at the secondary level from Central Michigan University, and a Bachelor's degree in English from Oakland University in Rochester, Michigan. He has extensive experience teaching at the middle school, high school, and college levels. His research interests include topics and issues associated with males and literacy. 